\title{
Preferences of Lifestyles in High School Students and Their Relation to Gender, School Achievement and Parents Education
}

\author{
Marija Mladenovska-Dimitrovska ${ }^{1, *}$, Aleksandar Dimitrovski ${ }^{2}$ \\ ${ }^{1}$ Secondary Municipal School Taki Daskalo, Department of Psychology, University Ss. Cyril and Methodius - Skopje and International \\ Slavic University "Gavrilo Romanovich Derzavin - Bitola, Republic of Macedonia \\ ${ }^{2}$ Primary School Krste Petkov Misirkov, Department of Psychology, International Slavic University "Gavrilo Romanovich Derzavin - \\ Bitola, Republic of Macedonia
}

Copyright (C) 2016 by authors, all rights reserved. Authors agree that this article remains permanently open access under the terms of the Creative Commons Attribution License 4.0 International License

\begin{abstract}
The aim of the research is to determine the lifestyle preferences in high school students, as well as to determine the differences in the preferences between respondents according to gender, school achievement and parents' education. The survey was conducted on a sample of 237 subjects, students of secondary schools in Bitola, Republic of Macedonia. In the research was used the Scale for measuring the value orientations by Popadić (1995), which measure 10 value orientations: family-sentimental, altruistic, cognitive, utilitarian, egoistic, hedonistic, religious-traditional, orientation to popularity, Promethean activism and orientation to power. The results showed that the most preferred lifestyle is a family-sentimental, which means that the family is one of the dominant values, following utilitarian lifestyle, egoistic and hedonistic orientation. At least preferred lifestyles are: orientation to popularity, orientation to power and cognitive lifestyle. There were no significant differences in terms of lifestyle preferences among the respondents of different gender, with exception of the orientation to popularity, which is more valued by the girls. Students who have less success at school more prefer the hedonistic orientation and orientation to popularity, while students who have better success at school, more value the cognitive lifestyle. Students whose parents are more educated more prefer the cognitive lifestyle of students whose parents have lower levels of education.
\end{abstract}

Keywords High School Students, Value Orientations, Lifestyles

\section{Introduction}

The dramatic social changes in a period of transition in Macedonia from socialism towards capitalism, necessarily leads to a changes in the value system, especially in young people, because we abandoned one system of values, which was established in the previous socialist system, and at the same time a new value system is not sufficiently formed and structured yet, which leads to confusion, disorientation in relation to desirable models of social behavior, inner turmoil and questioning. That's why it's important to research the system of values among young people, because they are the most sensitive to the changes, and they are in the middle between the system of values which it's been offered by the parents and family and the new changes that it's occurring in the society.

The study of value orientations and lifestyle preferences is very important, since they are a represent factors that guide and motivate the behavior of individuals and social groups.

The period of adolescence is considered a crucial to the development of system of values.

Adolescence is a period of development in which the individual values are formed under the influence of the socialization process and wider social developments. It is a period of live that is very sensitive to changes occurring in the society. This is the reason why the period of adolescence it's very interesting for research of the values.

This emphasis on the period of adolescence stems from the premise that there are many young in the process of crystallization of identity or self-determination, and it is assumed the special interest in adolescent values. At the same time, the values of youth may reflect the direction in which changes certain culture or society, and therefore they are of particular interest to researchers [1].

An educational process also plays an important role in the formation of value preferences and the value orientation of children and adolescents. If we want to effectively influence the process of its formation, it is necessary to know the values that children prefer, the values they consider significant in different stages of their lives. 


\section{Theoretical Framework}

Rokić, according to Rejk and Edkok [2], believes that the values are permanent belief that a specific mode of conduct or the way of life is personally or socially preferable to opposite pattern of behavior or lifestyle. Values are the socially desirable concepts used to represent these goals mentally and the vocabulary used to express them in social interaction, according to Schwartz [3]. Values can provide predictive and explanatory power in the analysis of attitudes, opinions and actions [4]. Schwartz in his theory defines values as desirable, trans situational goals, varying in importance, that serve as guiding principles in people's lives The crucial content aspect that distinguishes among values is the type of motivational goal they express [5].

Some authors make a distinction between the concepts of values and value orientations. Rot and Havelka [6,7], under the values means the relationship to the basic social ideas and norms, i.e., to relatively general and abstract objects, while under the value orientations they means general modes of operation and behavior of individuals in different situations. While Kuzmanović [8] believes that the values and value orientations are synonyms, and the difference is that the values means more articulated, more specific conception of the desirable and value orientations are wide, less articulate system of beliefs, less focused conception of the desirable.

As a common features that the various approaches attribute to the values, psychologists Schwartz and Bilsky, consider that the values are concepts or beliefs; the values are related to the desirable end states or behavior; they are beyond the specific situations; and they are vary according to the relative importance [9]. Values are cognitive representations of abstract goals (e.g., a world at peace) or abstract means of behaving (e.g., being helpful) that vary in desirability or importance. Similar to needs, desires, and goals, they function as motivational constructs that guide a person's behavior, but unlike specific goals and desires, they transcend situations (Rokeach, 1973; Schwartz, 1992; see Rohan, 2000) [10].

Gordon Allport (1961) suggested that value priorities were the "dominating force in life" because they directed all of a person's activity toward their realization, according to Rohan [10]. The values are conceived of as guiding principles in life which transcend specific situations may change over time, guide selection of behavior and events and which are part of a dynamic system with inherent contradictions [11]. Values are the result of socialization, they are influenced by individual experiences and social and cultural factors and the individual level significantly affect the attitudes and behaviors, according to Čulig et. al.[12].

The culture in which belongs the individual affects to the formation of his value system. Cultural value emphases shape and justify individual and group beliefs, actions, and goals. The preference element in cultural value orientations values as ideals - promotes coherence among the various aspects of culture. Because prevailing cultural value orientations represent ideals, aspects of culture that are incompatible with them are likely to generate tension and to elicit criticism and pressure to change, according to Schwartz [13].

A cultural value emphasis on success and ambition may be reflected in and promote highly competitive economic systems, confrontational legal systems, and child-rearing practices that pressure children to achieve [13]. Otherwise, in a society whose cultural value orientations emphasize collective responsibility, is less pressure for individual achievement, competition and ambition. Another important feature of cultural value orientations is that they are relatively stable (Hofstede, 2001; Schwartz, Bardi \& Bianchi, 2000) [14].

Adaptation to life circumstances influences value priorities primarily through two mechanisms - acclimation and compensation. For most types of values, people form value priorities are compatible with the reinforcement contingencies that their life circumstances afford. That is, they acclimate their values to their circumstances. They upgrade the importance of values they can readily attain and downgrade the importance of those whose pursuit is blocked [14].

When the attainment of values concerned with material well-being and security is largely beyond personal control, a compensation mechanism operates. These values are based on what Maslow called "deficit needs." Deprivation increases the strength of such needs and, correspondingly, of the valued goals to which they point (Bilsky \& Schwartz) [9]. For example, people who have endured economic hardship and social upheaval attribute more importance to the attainment of wealth and the preservation of social order (e.g., Inglehart, 1991; Schwartz, 1994) [15].

The main features of the conception of basic values implicit in the writings of many theorists and researchers as follows:

- Values are beliefs. But they are beliefs tied inextricably to emotion, not objective, cold ideas.

- Values are a motivational construct. They refer to the desirable goals people strive to attain.

- Values transcend specific actions and situations. They are abstract goals. The abstract nature of values distinguishes them from concepts like norms and attitudes, which usually refer to specific actions, objects, or situations.

- Values guide the selection or evaluation of actions, policies, people, and events. That is, values serve as standards or criteria.

- Values are ordered by importance relative to one another. People's values form an ordered system of value priorities that characterize them as individuals. This hierarchical feature of values also distinguishes them from norms and attitudes (Allport 1961; Feather, 1995; Inglehart, 1997; Kohn, 1969; Kluckhohn, 1951; Morris, 1956; Rokeach, 1973, according to Schwartz [16].

Each of the ten basic values can be characterized by 
describing its central motivational goal:

1. Self-Direction. Independent thought and action; choosing, creating, exploring.

2. Stimulation. Excitement, novelty, and challenge in life.

3. Hedonism. Pleasure and sensuous gratification for oneself

4. Achievement. Personal success through demonstrating competence according to social standards

5. Power. Social status and prestige, control or dominance over people and resources

6. Security. Safety, harmony, and stability of society, of relationships, and of self

7. Conformity. Restraint of actions, inclinations, and impulses likely to upset or harm others and violate social expectations or norms

8. Tradition. Respect, commitment, and acceptance of the customs and ideas that traditional culture or religion provide the self

9. Benevolence. Preserving and enhancing the welfare of those with whom one is in frequent personal contact (the 'in-group')

10. Universalism. Understanding, appreciation, tolerance, and protection for the welfare of all people and for nature [16]

According to Schwartz [17] the basic values that people in all cultures are likely to recognize. Similar value structures across culturally diverse groups suggest that there is a universal organization of human motives. Nevertheless, even if the human motives that values express and the structure of their relations are universal, individuals and groups differ substantially in the relative importance they place on particular values [17].

The system of values determines the behavior of an individual, i.e. determines his lifestyle. Lifestyle preference in their content are the most closer to the wider understanding of values, according to which the values are everything what a person likes or prefers.

According to Kuzmanović [18], the question of preferring the way of life means that a person has some idea of the possible way or ways of living, and that is why this concept as a way of life which seeks can be understood as a value orientation. Therefore, under the value orientations are understood more general goals, and under lifestyle the way to achieve those goals [18]. Some authors believe that lifestyles are the operationalization of the values [18]. Therefore, lifestyle is a relevant criterion for determining the value orientations. By identifying the preferences of the lifestyles we can determine the system of values of the individual.

The preference of any objective that we pursued is shaping our lives and particularly adolescents tend to fantasize about different options in life, think about their future and compare themselves with others. The preference of lifestyle is in line with our system of values and value orientations, and through the research of preferences of lifestyle, we can determine the value system of the individual. Commonly are studied these 10 lifestyles which are operationalized as follows:

- Family-sentimental style - means to meet a person who you will love and who will love you, to establish a family with and a person who you will completely devote, to find the meaning of life in the family.

- Altruistic orientation - means the individual to deal with something that is useful to other people, to help others, to help the unfortunate and disadvantaged people, even at the price of personal disclaimer.

- Cognitive orientation - means to engage in research, to trace the new inventions and discoveries, to gain more knowledge, constantly to learn new things about the world.

- Utilitarian lifestyle - means to want to have a well-paid job, which will bring a lot of money and material security, to provide a rich and comfortable life.

- Orientation to popularity - means to be popular, to be known in sports, music or entertainment, to appear on television, or in the newspapers, to have admirers.

- Egoistic orientation - means to regulate your life in a way to not depend on anyone, not to worry about other people and their concerns, to care primarily about yourself and your well-being.

- Promethean activism - means to advocate for the creation of better world and more equitable relationships in the environment and society, to fight for distant goals, ideas, ideals even when you encounter obstacles in the community.

- Hedonistic orientation - means to live carefree and cheerful live, to entertain, to enjoy the pleasures that life offers, to not save the money, but to spend on recreation and entertainment.

- Religious - traditional lifestyle - means to believe in God, to live in harmony with the teachings of the religion to which you belong, to find the spiritual peace in religion, to be a good believer, to respect the religious customs and holidays.

- Orientation to power - means to take managerial position in the society, to have a power, not to take orders from anyone, but to instruct others and to give orders to other people [19].

In this research we used this scale, constructed by Popadic, which is one of the most used instruments for measuring the value orientations in our country and in the region of former Yugoslavia.

The aim of this study was to determine the prevalence of particular lifestyles in high school students, to see which lifestyles are prominent among young people, as well as to determine the differences in preferences between respondents according to gender, school achievement and parents' education.

It is very important to gain knowledge about the system of values of young people and to make comparisons with previous researches to see if there are certain differences in the system of values among young people over the years. 


\section{Method}

\section{Sample}

The survey was conducted on a sample of 237 subjects, students of secondary schools in Bitola. The sample was selected at random. The sample was comprised of $48.8 \%$ of boys and $51.2 \%$ of girls. Average age of the respondents is $\mathrm{M}=16.95(\mathrm{SD}=0.798)$. In relation to the level of education of parents of the respondents, the situation is as follows: elementary education have completed $8 \%$ of fathers and $10.1 \%$ of mothers, secondary education have completed $51.9 \%$ of fathers and $53.9 \%$ of mothers, university degree or higher education have completed $40.1 \%$ of fathers and $36 \%$ of mothers.

\section{Instruments}

The rating scale used to measure the value orientations is the Scale of Popadic (1995), which contains 10 value orientations: family-sentimental, altruistic, cognitive, utilitarian, egoistic, hedonistic, religious-traditional, orientation to popularity, Promethean activism and orientation to power. The scale contains 5 degrees of accepting of a certain value orientations of Likert type. Metric characteristics of the instrument are satisfactory. Cronbach's alpha coefficient of internal consistency of the Scale is $\alpha=.866$, which is quite satisfactory.

\section{Results}

Based on the descriptive indicators, compared to the preferences of individual lifestyles, we got the following results:
Table 1. Means, standard deviations and ranks

\begin{tabular}{cccc}
\hline Lifestyles & M & SD & Rank \\
\hline Family-sentimental & 4,48 & 0,69 & 1 \\
Altruistic & 3,59 & 0,83 & 6 \\
Cognitive & 3,40 & 1,05 & 8 \\
Utilitarian & 4,41 & 0,69 & 2 \\
Orientation to popularity & 3,09 & 1,22 & 10 \\
Egoistic orientation & 4,00 & 0,80 & 3,5 \\
Promethean activism & 3,44 & 0,98 & 7 \\
Hedonistic orientation & 4,00 & 0,93 & 3,5 \\
Religious-traditional & 3,89 & 1,07 & 5 \\
Orientation to power & 3,30 & 0,17 & 9 \\
\hline
\end{tabular}

According to the obtained results, the most preferred lifestyle in the sample as a whole is a family-sentimental style, which means that the family is one of the dominant values, followed the utilitarian style, which reflecting the need for material security, which in time of economic crisis is more pronounced, while preference of the egoistic and hedonistic orientation reflects the tendency of the young people to satisfy their needs, to hedonism and enjoyment. The least preferred lifestyles are: orientation to popularity, orientation to power and cognitive lifestyle, which means that young people are not very prefer to have a power and control over others, it's not a dominant need for them to have a prestige and high position in society, to be popular in the community, which is expected according to their age and the stage of personal development, because they are in the period of live, when they are still building their identity. What is concerning in this results is the fact that among the young people lack the initiative to learn, to acquire knowledge and research. (Table 1).

Table 2. Inter correlations between subscales

\begin{tabular}{|c|c|c|c|c|c|c|c|c|c|c|}
\hline Lifestyles & I & II & III & IV & $\mathbf{V}$ & VI & VII & VIII & IX & $\mathbf{X}$ \\
\hline I. Family-sentimental & 1 & & & & & & & & & \\
\hline II. Altruistic & $.727 * *$ & 1 & & & & & & & & \\
\hline III. Cognitive & -.060 & $.401 * *$ & 1 & & & & & & & \\
\hline IV. Utilitarian & $.701 * *$ & -.047 & .056 & 1 & & & & & & \\
\hline V. Orientation to popularity & .048 & .040 & .008 & $.607 * *$ & 1 & & & & & \\
\hline VI. Egoistic orientation & .042 & $-.576 * *$ & .012 & $.835 * *$ & -.008 & 1 & & & & \\
\hline VII. Promethean activism & $.688 * *$ & $.437 * *$ & $.383^{*}$ & .119 & -.069 & .121 & 1 & & & \\
\hline VIII. Hedonistic orientation & -.076 & -.081 & $-.462 *$ & $.230 *$ & .100 & $.649 *$ & .035 & 1 & & \\
\hline X. Orientation to power & $.332 *$ & -.046 & -.039 & $.432 * *$ & $.415^{* *}$ & .028 & .027 & .080 & .104 & 1 \\
\hline
\end{tabular}

$\mathrm{p}<.05 * \mathrm{p}<.01 * *$ 
As we can see from the inter correlations between the 10 lifestyles (Table 2), there are the significant positive correlations between the family-sentimental lifestyle, altruistic, promethean activism, religious-traditional and orientation to power. This tells us that respondents who were more valued family-traditional values are more inclined to value and universal values and they are more committed to the common good. These lifestyles make up the so-called common human orientation. The positive correlation exists between the altruism and religious-traditional lifestyle, which means that those participants in which are more expressed the traditional-religious values are more altruistic. On the other hand, a significant negative correlation was obtained between altruism, and egoistic orientation, which is expected.

Significant positive correlations were obtained between utilitarian lifestyle, orientation to popularity, egoistic, hedonistic orientation and the orientation to power, which tells us that respondents who were more preferred these lifestyles, are more targeted to personal well-being and to satisfy their own needs.

Hedonistic orientation is negatively correlated with cognitive lifestyle, suggesting that young people who are more aimed to leisure and hedonism less value the knowledge. Cognitive lifestyle is positively correlated with Promethean activism and religious-traditional lifestyle.

Inter correlations between individual lifestyles suggest that the system of values of the young people is separated in two general orientations: a common human orientation which includes traditional-family values and Promethean activism and general welfare, and the other orientation that covers the egoistic-hedonistic values and orientation towards personal well-being and benefit, and to satisfy their own needs.

There were no statistically significant differences in preferences of lifestyles among the students of different gender, with exception of the orientation to popularity, where there is a significant difference between boys and girls in the girls' favor. (Table 3).

In relation to the school success, we calculated the Pearson coefficient of correlation and we found that there is a significant negative correlation with the hedonistic orientation $(\mathrm{r}=-0.24, \mathrm{p}<.01)$ and with orientation to popularity $(r=-0.13, p<.05)$, which means that students of lower success in school more prefer the hedonistic orientation and orientation to popularity, while students who have better success in school more favored the cognitive lifestyle $(r=0.14, p<.05)$. Compared to other lifestyles we have not found a statistically significant correlation (Table 4).

Table 3. Differences in preferences of lifestyles among the respondents of different gender

\begin{tabular}{|c|c|c|c|c|c|c|}
\hline Lifestyles & Gender & $\mathbf{M}$ & SD & t-test & df & Sig. \\
\hline \multirow[b]{2}{*}{ Family-sentimental } & M & 4.42 & .615 & \multirow{2}{*}{-1.020} & \multirow{2}{*}{235} & \multirow{2}{*}{.309} \\
\hline & W & 4.52 & .727 & & & \\
\hline \multirow[b]{2}{*}{ Altruistic } & M & 3.55 & .856 & \multirow{2}{*}{-.539} & \multirow{2}{*}{235} & \multirow{2}{*}{.591} \\
\hline & $\mathrm{W}$ & 3.61 & .810 & & & \\
\hline \multirow[b]{2}{*}{ Cognitive } & M & 3.46 & 1.094 & \multirow{2}{*}{.695} & \multirow{2}{*}{235} & \multirow{2}{*}{.487} \\
\hline & W & 3.36 & 1.032 & & & \\
\hline \multirow[b]{2}{*}{ Utilitarian } & $\mathrm{M}$ & 4.46 & .717 & \multirow{2}{*}{.843} & \multirow{2}{*}{235} & \multirow{2}{*}{.400} \\
\hline & W & 4.38 & .667 & & & \\
\hline \multirow{2}{*}{$\begin{array}{c}\text { Orientation to } \\
\text { popularity }\end{array}$} & M & 2.87 & 1.203 & \multirow{2}{*}{-2.684} & \multirow{2}{*}{235} & \multirow{2}{*}{$.008 *$} \\
\hline & W & 3.30 & 1.238 & & & \\
\hline \multirow[b]{2}{*}{ Egoistic orientation } & M & 3.98 & .889 & \multirow{2}{*}{-.268} & \multirow{2}{*}{235} & \multirow{2}{*}{.789} \\
\hline & W & 4.01 & .741 & & & \\
\hline \multirow{2}{*}{$\begin{array}{c}\text { Promethean } \\
\text { activism }\end{array}$} & M & 3.41 & 1.007 & \multirow{2}{*}{-.321} & \multirow{2}{*}{235} & \multirow{2}{*}{.749} \\
\hline & $\mathrm{W}$ & 3.46 & .972 & & & \\
\hline \multirow{2}{*}{$\begin{array}{l}\text { Hedonistic } \\
\text { orientation }\end{array}$} & M & 4.07 & .935 & \multirow{2}{*}{.806} & \multirow{2}{*}{235} & \multirow{2}{*}{.421} \\
\hline & W & 3.97 & .924 & & & \\
\hline \multirow[b]{2}{*}{ Religious-traditional } & M & 3.74 & 1.098 & \multirow{2}{*}{-1.743} & \multirow{2}{*}{235} & 083 \\
\hline & W & 3.99 & 1.038 & & & .083 \\
\hline & M & 3.28 & 1.225 & 219 & 235 & 827 \\
\hline Orientation to power & W & 3.32 & 1.165 & -.219 & $2 J 3$ & .021 \\
\hline
\end{tabular}
$\mathrm{p}<.05 * \mathrm{p}<.01 * *$

Table 4. The Pearson coefficient of correlation between the lifestyles and the school success

\begin{tabular}{cc}
\hline Lifestyles & School success \\
\hline Family-sentimental & 0.07 \\
Altruistic & -0.01 \\
Cognitive & $0.14^{*}$ \\
Utilitarian & -0.02 \\
Orientation to popularity & $-0.13^{*}$ \\
Egoistic orientation & -0.10 \\
Promethean activism & -0.01 \\
Hedonistic orientation & $-0.24 * *$ \\
Religious-traditional & -0.12 \\
Orientation to power & -0.03 \\
\hline
\end{tabular}

$\mathrm{p}<.05 * \mathrm{p}<.01 * *$ 
In relation to the level of parental education we calculated Analysis of variance and there are not significant differences in preferences of lifestyles in relation to the level of father's education (Table 5).

Table 5. Analysis of variance - differences in preferences of lifestyles among the respondents according to the level of education of father

\begin{tabular}{|c|c|c|c|c|c|c|}
\hline \multicolumn{2}{|c|}{ Lifestyles } & Sum of squares & df & Mean square & $\mathbf{F}$ & sig \\
\hline \multirow{3}{*}{ Family sentimental } & Between the groups & .844 & 2 & .422 & \multirow{3}{*}{.895} & \multirow{3}{*}{.410} \\
\hline & Within the groups & 110.320 & 235 & .471 & & \\
\hline & Total & 111.165 & 237 & & & \\
\hline \multirow{3}{*}{ Altruistic } & Between the groups & .283 & 2 & .142 & \multirow{3}{*}{.206} & \multirow{3}{*}{.814} \\
\hline & Within the groups & 161.017 & 235 & .688 & & \\
\hline & Total & 161.300 & 237 & & & \\
\hline \multirow{3}{*}{ Cognitive } & Between the groups & 5.831 & 2 & 2.915 & \multirow{3}{*}{2.656} & \multirow{3}{*}{.072} \\
\hline & Within the groups & 256.887 & 235 & 1.098 & & \\
\hline & Total & 262.717 & 237 & & & \\
\hline \multirow{3}{*}{ Utilitarian } & Between the groups & .094 & 2 & .047 & \multirow{3}{*}{.099} & \multirow{3}{*}{.905} \\
\hline & Within the groups & 111.205 & 235 & .475 & & \\
\hline & Total & 111.300 & 237 & & & \\
\hline \multirow{3}{*}{ Orientation to popularity } & Between the groups & .887 & 2 & .444 & \multirow{3}{*}{.290} & \multirow{3}{*}{.748} \\
\hline & Within the groups & 357.771 & 235 & 1.529 & & \\
\hline & Total & 358.658 & 237 & & & \\
\hline \multirow{3}{*}{ Egoistic orientation } & Between the groups & .431 & 2 & .216 & \multirow{3}{*}{.335} & \multirow{3}{*}{.716} \\
\hline & Within the groups & 150.565 & 235 & .643 & & \\
\hline & Total & 150.996 & 237 & & & \\
\hline \multirow{3}{*}{ Promethean activism } & Between the groups & 1.103 & 2 & .551 & \multirow{3}{*}{.568} & \multirow{3}{*}{.568} \\
\hline & Within the groups & 227.260 & 235 & .971 & & \\
\hline & Total & 228.363 & 237 & & & \\
\hline \multirow{3}{*}{ Hedonistic orientation } & Between the groups & .249 & 2 & .125 & \multirow{3}{*}{.144} & \multirow{3}{*}{.866} \\
\hline & Within the groups & 202.746 & 235 & .866 & & \\
\hline & Total & 202.996 & 237 & & & \\
\hline \multirow{3}{*}{ Religious - traditional } & Between the groups & 1.517 & 2 & .758 & \multirow{3}{*}{.665} & \multirow{3}{*}{.515} \\
\hline & Within the groups & 265.619 & 235 & 1.140 & & \\
\hline & Total & 267.136 & 237 & & & \\
\hline \multirow{3}{*}{ Orientation to power } & Between the groups & .088 & 2 & .044 & \multirow{3}{*}{.031} & \\
\hline & Within the groups & 332.038 & 235 & 1.419 & & .964 \\
\hline & Total & 332.127 & 237 & & & \\
\hline
\end{tabular}


In relation to the level of maternal education, Variance analysis (Table 6) indicates that there are differences in preferences of the cognitive lifestyle, while with the Post-hoc analysis, i.e. Schefft test, we found that the subjects whose mothers have completed higher education (university degree), the highest valued the cognitive lifestyle, while those respondents whose mothers have completed only primary school at least evaluate cognitive lifestyle.

Table 6. Analysis of variance - differences in preferences of lifestyles among the respondents according to the level of education of mother

\begin{tabular}{|c|c|c|c|c|c|c|}
\hline \multicolumn{2}{|c|}{ Lifestyles } & Sum of squares & df & Mean square & $\mathbf{F}$ & sig \\
\hline \multirow{3}{*}{ Family sentimental } & Between the groups & .290 & 2 & .145 & \multirow{3}{*}{.306} & \multirow{3}{*}{.736} \\
\hline & Within the groups & 110.874 & 235 & .474 & & \\
\hline & Total & 111.165 & 237 & & & \\
\hline \multirow{3}{*}{ Altruistic } & Between the groups & .856 & 2 & .428 & \multirow{3}{*}{.624} & \multirow{3}{*}{.537} \\
\hline & Within the groups & 160.444 & 235 & .686 & & \\
\hline & Total & 161.300 & 237 & & & \\
\hline \multirow{3}{*}{ Cognitive } & Between the groups & 9.378 & 2 & 4.689 & \multirow{3}{*}{4.331} & \multirow{3}{*}{$.001 * *$} \\
\hline & Within the groups & 253.339 & 235 & 1.083 & & \\
\hline & Total & 262.717 & 237 & & & \\
\hline \multirow{3}{*}{ Utilitarian } & Between the groups & .220 & 2 & .110 & \multirow{3}{*}{.232} & \multirow{3}{*}{.793} \\
\hline & Within the groups & 111.080 & 235 & .475 & & \\
\hline & Total & 111.300 & 237 & & & \\
\hline \multirow{3}{*}{ Orientation to popularity } & Between the groups & 2.040 & 2 & 1.020 & \multirow{3}{*}{.669} & \multirow{3}{*}{.313} \\
\hline & Within the groups & 356.618 & 235 & 1.524 & & \\
\hline & Total & 358.658 & 237 & & & \\
\hline \multirow{3}{*}{ Egoistic orientation } & Between the groups & 1.375 & 2 & .678 & \multirow{3}{*}{1.075} & \multirow{3}{*}{.343} \\
\hline & Within the groups & 149.621 & 235 & .639 & & \\
\hline & Total & 150.996 & 237 & & & \\
\hline \multirow{3}{*}{ Promethean activism } & Between the groups & 3.116 & 2 & 1.558 & \multirow{3}{*}{1.618} & \multirow{3}{*}{.200} \\
\hline & Within the groups & 225.247 & 235 & .963 & & \\
\hline & Total & 228.363 & 237 & & & \\
\hline \multirow{3}{*}{ Hedonistic orientation } & Between the groups & 1.562 & 2 & .781 & \multirow{3}{*}{.907} & \multirow{3}{*}{.405} \\
\hline & Within the groups & 201.434 & 235 & .861 & & \\
\hline & Total & 202.996 & 237 & & & \\
\hline \multirow{3}{*}{ Religious - traditional } & Between the groups & 4.116 & 2 & 2.058 & \multirow{3}{*}{1.823} & \multirow{3}{*}{.164} \\
\hline & Within the groups & 263.020 & 235 & 1.129 & & \\
\hline & Total & 267.136 & 237 & & & \\
\hline \multirow{3}{*}{ Orientation to power } & Between the groups & 3.379 & 2 & 1.688 & \multirow{3}{*}{1.202} & \\
\hline & Within the groups & 328.748 & 235 & 1.405 & & .302 \\
\hline & Total & 332.127 & 237 & & & \\
\hline
\end{tabular}

$\mathrm{p}<.01 * *$ 


\section{Discussion and Conclusions}

It is expected that the family-sentimental style is the most preferred, given the age of the respondents who are in the stage of development when they are establishing their heterosexual relationships, when they have a pronounced need for belonging, security, and also considering the fact that the family is one of the dominant values in our society. In some previous studies, for example, the research of Popadić [20] in Serbia, and the research of Stojanović in 2001 in Macedonia [21], family-sentimental style also is the most preferred. And the researches that were done recently in the high school population in Macedonia, by Stojanova and Miloševa [22], and in the study of Jovkovska and Barakoska [23], the family-sentimental style also is the most preferred.

Highly evaluating of the hedonistic-utilitarian style indicates that young people fulfill their goals and needs by the hedonistic principle, that among young people is increasingly prominent and one of the dominant need, the need for the acquisition of material goods, the need for material security, the young people prefer to have a well-paid job, easy way of life, filled with lots of fun, enjoyment and spending money, which is somewhat expected considering the period of development in which they are, and the influence of the modern consumer society. Similar findings are found in studies that are conducted in Macedonia by Stojanova \& Miloševa [22] and Jovkovska and Barakoska [23] and in the research in Serbia that was made by Petrović and Zotović [24]. Also in the research of Joksimovic one of the most preferred lifestyles are the utilitarian and hedonistic style [25].

According to Luković and Čismić [26], orientation towards the acquisition and material security is becoming more and more prominent, dominant and widespread, which is typical for societies that are in transition. In a situation of transition and economic crisis in which our society is, it is very characteristically that the individual is directed towards their welfare and benefits and to satisfy their needs and survival.

Altruistic style and Promethean activism are less attractive, which points to the fact that young people are more accepting the egoistic values and fight for their survival and less valued and prices communion, solidarity and commitment to the general welfare (the similar findings we found in the study of Stojanova and Miloševa [22], and in the research of Joksimovic [25] in contrast in some previous studies, where the altruistic style was one of the most preferred, as we found in the research of Popadic [20]. Minor expression of altruistic orientation attributed to the fear of material deprivation and social-economic crisis in society.

At least preferred lifestyles are orientation to popularity and orientation to power, it has been established in other studies (Petrović and Zotović [24]; Jovkovska and Barakoska [23]. It is disturbing that the cognitive lifestyle is one of the three least preferred, indicating that young people less value and prices the knowledge, which is evident in recent years. Similar findings we found in the survey that was done by Stojanova and Miloševa [22], where also the cognitive style is one of the least preferred. In the study of Stojanović [21] which it's been done at the beginning of the past decade, more precise in the 2001, the cognitive lifestyle was one of the most preferred and had rank fourth. Also in the research of Popadic [20], which it's been made in the 1990, the cognitive lifestyle was one of the tree most preferred. The lower valuation of knowledge as a value is due to the anomy of the system of values in our society today, where the individual acknowledges that education and knowledge are no longer powerful tools to achieve their goals.

The perception of the importance of school and learning as a means of achieving the life goals is influenced by family and the wider social environment [8], and so it follows that young people whose parents are less educated, themselves show underachievement in school and less valued the cognitive lifestyle, and much more valued the hedonistic. Respondents whose parents are more educated, highly valued the cognitive lifestyle, which is probably connected with the social position and intellectual atmosphere in the family. The education level of the mother proved to be important for a greater acceptance of the cognitive lifestyle, which is likely to exceed that more educated mothers more valued and prices the knowledge and these values are transmitted to the children, because mothers are more involved in the process of education of the children.

Respondents who have better achievement at school more valued the cognitive lifestyle, while those with lower achievement at school more valued the popularity. There were no gender differences in relation to the preferences of certain lifestyles, except for the orientation to the popularity, which is more evaluated by the female respondents. Girls more than the boys, prefer to be popular, to be known, to have a higher social status, to follow fashion trends.

We can conclude that this research indicates certain tendencies and changes in the value system of the young people, compared to some previous researches, but also shows certain continuity, especially in relation to the family as a value. This tells us that for young people it's very important to realize the emotional connection, to love and to be loved, to achieve emotional security, to belong to someone, to create a family. Changes in the values are related to the growing popularity of the utilitarian and hedonistic style in young people and lower valuation of the altruistic orientation and the Promethean activism, as well as the cognitive lifestyle. This tells us that young people are more oriented towards personal well-being and benefits, and less to the commitment for the general welfare and well-being of others (similar tendencies found Joksimovic and Maksic in 2006 [27]) and that young people are less likely prices the knowledge as a value and as a means to achieve the personal success. This may be due to a long period of transition, through which our society is past all this years, since we left the socialism and Yugoslav federation and we gained the independence and we established the 
capitalism. In the socialism we had one system of values in which the dominant values were the family, solidarity and common good, and now the focus is on personal wellbeing.

It is important to gain insight into the system of dominant values among young people, because they are the future of our society, and they will transfer their system of values to the future generations. The system of values of individuals it's always influenced by the wider social environment and reflects the social changes, so it is a good indicator of the direction in which our society is moving.

In a period of transition in which our society is, often comes to anomy of the system of values and confusion, which is especially pronounced among young people, who are torn between what is imposed on them as a value from outside, from the social environment and what is imposed on them as a value from the parents who grew up, formed personalities and built their values in another and different social system.

It's expected a smaller preference of altruism and promethean activism which were more a reflection of the former socialist system, and it's also expected the greater preference of hedonistic-egoistic orientation which are more characteristic of modern capitalistic and consumer society. What is surprising and it should concerned us is reduced preference of cognitive lifestyle, because it tells us that we have the erosion of knowledge as a value and that young people are less focused on achieving knowledge, they have no interest in learning, no motivation for learning and they believe that their life goals can be achieved by other methods, not by knowledge and learning. In that part these research findings should especially worry us and to motivate all of us, as a society, particularly all the factors involved in the educational process to take concrete measures to reform the educational system, which will be directed towards the acquisition of knowledge of students and to develop their motivation to learn and achieve results and embed system of values among young people that only with knowledge and learning they will achieve their goals in life.

This research has given us insight into the prevalence of certain lifestyles among young people. In some future research we could examine the impact of the complex socio-political factors on values and value orientations and the preference of lifestyles.

\section{REFERENCES}

[1] Franc R, Sučić I, Šakić V. Vrijednosti kao rizični i zaštitni čimbenici socijalizacije mladih. Diacovensia. 2009 Apr 30;16(1-2):135-46

[2] Rejk, B. \& Edkok, K. (1978). Vrednosti, stavovi i promena ponašanja. Beograd: Nolit.

[3] Schwartz SH. An overview of the Schwartz theory of basic values. Online Readings in Psychology and Culture. 2012;2(1):11
[4] Schwartz SH. A proposal for measuring value orientations across nations. Questionnaire Package of the European Social Survey. 2003:259-90.

[5] Schwartz S. Value Priorities and Behavior: Applying. In The psychology of values: The Ontario symposium 2013 May 13 (Vol. 8). Psychology Press.

[6] Рот, Н. и Хавелка, Н. (1973). Национална везаност и вредности код средношколске омладине. Београд: Институт за психологију и Институт за друштвене науке.

[7] Havelka, N. (1995). Vrednosne orijentacije učenika i njihova očekivanja od budučeg zanimanja. Psihološka istraživanja 7 , 89-125.

[8] Kuzmanović, B. (1995). Društvene promene vrednosnih orijentacija učenika. Psihološka istraživanja 7, 17-47. Beograd: Institut za psihologiju.

[9] Bilsky W, Schwartz SH. Values and personality. European journal of personality. 1994 Sep 1;8(3):163-81.

[10] Rohan MJ. A rose by any name? The values construct. Personality and social psychology review. 2000 Aug $1 ; 4(3): 255-77$.

[11] Debats DL, Bartelds BF. The structure of human values: a principal components analysis of the Rokeach Value Survey (RVS). Website: http://www. dissertations. ub. rug. nl/FILES/faculties/ppsw/1996/dlhm debats/c5. pdf (Erişim: 05.12. 2011). 1996.

[12] Čulig, B., Fanuko, N., Jerbić, V. Vrijednosti i vrijednosne orijentacije mladih. Rezultati istraživanja provedenog u SR Hrvatskoj 1981. godine, Centar društvenih djelatnosti Saveza Socijalističke omladine Hrvatske, Zagreb, 1982.

[13] Schwartz SH. A theory of cultural value orientations: Explication and applications. Comparative sociology. 2006 Jun 1;5(2):137-82.

[14] Schwartz SH, Bardi A, Bianchi G. Value adaptation to the imposition and collapse of communist regimes in East-Central Europe. Political psychology: Cultural and cross-cultural foundations. 2000:217-37.

[15] Schwartz SH. Are There Universal Aspects in the Structure and. Journal of social issues? 1994;50(4):19-45

[16] Schwartz SH. Basic human values: Theory, measurement, and applications. Revue française de sociologie. 2006; 47(4):249-88.

[17] Schwartz SH. Basic values: How they motivate and inhibit prosocial behavior. Prosocial motives, emotions, and behavior: The better angels of our nature. 2010;14:221-41.

[18] Kuzmanović, B. (1986). Preferencije načina života. Filozofskog fakulteta, 14, 5-67.Zbornik

[19] Popadić, D. (1995). Uzrasne i generacijske razlike u preferenciji životnih stilova. Psihološka istraživanja 7, 71-88. Beograd: Institut za psihologiju.

[20] Popadić, D. (1990): Učeničke preferencije načina života; u N. Havelka i sar.: Efekti osnovnog školovanja (235-259). Beograd: Institut za psihologiju.

[21] Стојановиќ, М. (2001). Преференциите на животните стилови кај осмоодделенците. Дипломска работа. Скопје: Филозофски факултет. 
[22] Стојанова, Б. и Милошева, Л. (2009). Вредносните ориентации кај адолесцентите. Воспитание - списание за теорија и практика. Бр. 10., стр. 55-61. Штип: Универзитет Гоце Делчев.

[23] Jovkovska, A. \& Barakoska, A. (2014). The role of education in the formation of values and value orientations among adolescents. International Journal of Cognitive Research in Science, Engineering and Education, Vol.2, No.2

[24] Petrović, J. i Zotović, M. (2012). Adolescenti u Srbiji: U traganju za novim vrednostima. Teme, 1/2012, str. 47-66.
[25] Joksimović, S. 1992. Odnos učenika prema pojedinim stilovima života kao pokazatelj njihovih vrednosnih orijentacija. Psihologija 25(1-2):7-23.

[26] Luković, S. i Čismić, S. Povezanost preferencijama životnih stilova i profesionalnih interesovanja petnaestogodišnjaka. Primenjena psihologija 2012/1, str. 81-108. Novi Sad: Filozofski fakultet, Odsek za psihologiju.

[27] Joksimovic, S. i Maksic, S. Vrednosne orijentacije adolescenata: Usmerenost prema sopstvenoj dobrobiti i dobrobiti drugih. Zbornik Instituta za pedagoška istraživanja. 2006 Br.2. str. 415-429. 